Article

\title{
Wave Overtopping Discharge for Very Gently Sloping Foreshores
}

\author{
Thu-Ha Nguyen ${ }^{1,2, *} \mathbb{D}$, Bas Hofland ${ }^{1}{ }^{(\mathbb{D}}, \mathrm{Vu}$ Dan Chinh $^{2}$ and Marcel Stive ${ }^{1}$ \\ 1 Faculty of Civil Engineering and Geosciences, Delft University of Technology, Stevinweg 1, \\ 2628 CN Delft, The Netherlands; B.Hofland@tudelft.nl (B.H.); M.J.F.Stive@tudelft.nl (M.S.) \\ 2 Faculty of Coastal and Offshore Engineering, National University of Civil Engineering, \\ Hanoi 100000, Vietnam; chinhvd@nuce.edu.vn \\ * Correspondence: H.Nguyen-1@tudelft.nl; Tel.: +31-0614-271-599
}

Received: 11 May 2020; Accepted: 10 June 2020; Published: 13 June 2020

\begin{abstract}
The spectral wave period $\mathrm{T}_{\mathrm{m}-1,0}$ at the toe of sea-dikes is a crucial parameter to predict wave overtopping discharge over sea-dikes. It is known from literature that this period quickly increases when waves reach shallow foreshores; however, sometimes the assumption is made that the wave period remains constant from offshore to near-shore, leading to an underestimation of the near-shore wave period. Several formulae have been proposed to resolve the underestimation of wave overtopping discharges for very shallow foreshores. These corrective formulations confirm the tendency of underestimating the overtopping discharges over a very gently sloping foreshore but are not validated for foreshore slopes gentler than 1:500. The "equivalent slope" method based on a recent study is inappropriate for these very gently sloping foreshores due to the breaker parameter being much smaller than seven. This study proposes an extension of the correction and finds that spectral wave periods can reach values two times those offshore.
\end{abstract}

Keywords: SWAN; SWASH; wave overtopping; LF waves; $\mathrm{T}_{\mathrm{m}-1,0}$; (very) shallow foreshore; very gentle foreshore

\section{Introduction}

The Vietnamese coastline is very diverse and quite unique in many respects, such as coastal types, coastline orientation and wave and tidal characteristics [1]. The wave characteristics in the North and in the South are very much influenced by the very gentle (ranging from 1 in 500 to 1 in 1000-in the Mekong Delta) and shallow foreshores that are a result of the locally very wide shelfs. There is a strong tradition at the northern and southern shores to protect the hinterland against flooding by dikes. In the dike design international guidelines on wave overtopping are applied. Based on recent findings, the EurOtop manual [2] indicates that the wave overtopping discharges are not able to properly account for gentle foreshores (order of 1 in 100). This study investigates this issue for even gentler foreshores.

The focus is on two physical parameters, viz., the relevant spectral wave period and the mean overtopping discharge. Since no data exist for these very gentle foreshores, this study relies on a recent state-of-the-art nearshore time domain wave model SWASH [3].

First, this paper starts with a literature review focusing on the wave overtopping of dikes at very shallow foreshores. Next, a site description is given of the North Vietnamese coast, which shows the presence of very shallow associated with very gently sloping foreshores. An exploratory calculation is made using the shallow water wave model SWAN to illustrate the wave processes that occur. This model is used to propagate the wave spectra from far offshore to the near shore. In the SWASH setup section, the configurations are described by the numerical calculations that have been performed to determine the spectral wave period and wave overtopping at very gentle foreshores. The results are 
used as a boundary condition for the non-hydrostatic wave propagation model SWASH. In parallel, the SWASH model is validated by reproducing the results of the Van Gent [4] and Altomare formulae [5]. Third, the spectral wave period $\mathrm{T}_{\mathrm{m}-1,0}$-for (very) shallow foreshores on both mild and very gentle slopes and the mean overtopping discharge (q)-for very gently sloping foreshores are calculated. Cases with very shallow foreshores are calculated, in combination with empirical formulae. The last part of the paper ends with discussions and conclusions given.

\subsection{State-of-the-Art in Deriving the Spectral Wave Period for Different Foreshores}

The spectral wave period is defined based on the first negative wave spectral moment:

$$
\begin{gathered}
\mathrm{T}_{\mathrm{m}-1,0}=\frac{\mathrm{m}_{-1}}{\mathrm{~m}_{0}} \\
\text { and } \mathrm{m}_{\mathrm{k}}=\int_{0}^{\infty} \mathrm{f}^{\mathrm{k}} \mathrm{S}(\mathrm{f}) \mathrm{df}
\end{gathered}
$$

where $m_{k}$ is the $k^{\text {th }}$ moment of the wave spectrum, and $f$ and $S$ are the wave frequency $\left[\mathrm{s}^{-1}\right]$ and the energy density $\left[\mathrm{m}^{2} \mathrm{~s}\right]$, respectively.

Van Gent $[4,6,7]$ indicated that the spectral wave period $\mathrm{T}_{\mathrm{m}-1,0}$ at the dike toe is one of the most relevant parameters for both wave run-up and overtopping predictions. $T_{m-1,0}$ weighs the low-frequency (LF) spectral energy more than the high-frequency (HF) spectral energy. The LF waves are generated in the shoaling and surf zone after being released from the high-frequency (HF) wave groups $[8,9]$. Furthermore, for non-standard spectral shapes, when the response of coastal structures (e.g., overtopping) is described by $\mathrm{T}_{\mathrm{m}-1,0}$, these responses are not dependent on the wave spectral type, even if the spectral shape is flattened in shallow water $[2,10]$.

A prediction formula for the spectral wave period $T_{m-1,0}$ has been given by Hofland [11] for shallow to extremely shallow water with a gently sloping bed slope. According to Hofland [11] the increase of $\mathrm{T}_{\mathrm{m}-1,0}$ is:

$$
\frac{T_{m-1,0, t}}{T_{m-1,0, o}}-1=6 \exp (-4 \widetilde{h})+\exp (-\widetilde{h})
$$

where

$$
\widetilde{\mathrm{h}} \text { is relative depth, } \widetilde{\mathrm{h}}=\frac{\mathrm{h}_{\mathrm{t}}}{\mathrm{H}_{\mathrm{m} 0, \mathrm{o}}}\left(\frac{\cot \theta}{100}\right)^{0.2}
$$

$T_{m-1,0}$ quickly increases when waves attack the shallow foreshores and can reach values roughly eight times compared with those offshore. Shallow and very shallow foreshores were defined as $1<\mathrm{h}_{\text {toe }} / \mathrm{H}_{\mathrm{m} 0, \mathrm{o}}<4$ and $0.3<\mathrm{h}_{\mathrm{toe}} / \mathrm{H}_{\mathrm{m} 0, \mathrm{o}}<1$, respectively. Mild sloping foreshores as discussed by Van Gent [4] are limited to $\cot \theta<250$.

\subsection{State-of-the-Art in Wave Overtopping Formulae for Sea-Dikes with Steep, Mild, and Very Gentle Foreshores}

The formulae suggested by Van Gent [4] and applied in TAW [12] and EurOtop I [10] are expressed as follows:

$$
\frac{\mathrm{q}}{\sqrt{\mathrm{g} \cdot \mathrm{H}_{\mathrm{m} 0}^{3}}}=10^{\mathrm{c}} \exp \left(-\frac{\mathrm{R}_{\mathrm{C}}}{\mathrm{H}_{\mathrm{m} 0} \cdot \gamma_{\mathrm{f}} \cdot \gamma_{\beta} \cdot\left(0.33+0.022 \xi_{\mathrm{m}-1,0}\right)}\right)
$$

With a maximum of

$$
\frac{\mathrm{q}}{\sqrt{\mathrm{g} \cdot \mathrm{H}_{\mathrm{m} 0}^{3}}}=0.21 \cdot \exp \left(-\frac{\mathrm{R}_{\mathrm{C}}}{\mathrm{H}_{\mathrm{m} 0} \cdot \gamma_{\mathrm{f}} \gamma_{\beta}\left(0.33+0.022 \xi_{\mathrm{m}-1,0}\right)}\right)
$$


The factor $\mathrm{c}$ is considered as a normally distributed parameter with mean value and standard deviation of -0.92 and 0.24 , respectively. These two equations are recommended for $\xi_{m-1,0} \geq 7$. In case $\xi_{\mathrm{m}-1,0} \leq 5$, two equations are valid as below:

$$
\frac{\mathrm{q}}{\sqrt{\mathrm{g} \cdot \mathrm{H}_{\mathrm{m} 0}^{3}}}=\frac{0.067}{\sqrt{\tan \alpha}} \gamma_{\mathrm{b}} \xi_{\mathrm{m}-1,0} \exp \left(-4.75 \frac{\mathrm{R}_{\mathrm{C}}}{\mathrm{H}_{\mathrm{m} 0} \cdot \gamma_{\mathrm{f}} \cdot \gamma_{\beta} \cdot \gamma_{\nu} \cdot \gamma_{\mathrm{b}} \cdot \xi_{\mathrm{m}-1,0}}\right)
$$

With a maximum of

$$
\frac{\mathrm{q}}{\sqrt{\mathrm{g} \cdot \mathrm{H}_{\mathrm{m} 0}^{3}}}=0.2 \cdot \exp \left(-2.6 \frac{\mathrm{R}_{\mathrm{C}}}{\mathrm{H}_{\mathrm{m} 0} \cdot \gamma_{\mathrm{f}} \cdot \gamma_{\beta}}\right)
$$

In case $5 \leq \xi_{m-1,0} \leq 7$, a linear interpolation is applied between the two above cases.

These equations have been improved by Altomare [5] for application to even more shallow water depths, which has been adopted in the second release of the EurOtop II manual [2]. Altomare [5] indicated that Van Gent's formulae overestimated the mean overtopping discharge in very shallow water foreshores and recommended a new "equivalent slope" concept for appropriate mean overtopping discharge with shallow and very shallow waters.

Very gentle and shallow coastal shelfs are often found in mangrove areas, since fine sediments dominate in these areas. The very gently sloping foreshores can cause a large change of wave spectra at dike toes compared with that at offshore locations. Vietnamese sandy coasts are typically represented by mildly sloping foreshores in the North and even very mild bottom slopes in the South [13-15]. Compared to previous studies, the typical foreshores for Vietnamese coasts are very gentle, and are more gentle than those considered in EurOtop II [2]. Very gentle foreshores in combination with shallow water zone can cause wave breaking far from the shore and a remarkable change of wave spectra from offshore to near shore. The effect of these very gently sloping foreshores on wave overtopping is not yet well quantified.

Therefore, the purpose of this paper is to derive a suitable method to determine the mean overtopping discharge on very gently sloping foreshores and propose the use of extended wave overtopping discharge formulae for this type of foreshores.

\section{Materials and Methods}

\subsection{Site Description}

To illustrate the importance of wave overtopping discharge over a very gentle slope, a gently sloping foreshore in the North of Vietnam is taken as an illustrative case study. A very long cross-shore trajectory of $180 \mathrm{~km}$ to the near-shore will be investigated where the maximum water depth in the offshore reaches $70 \mathrm{~m}$ due to the fact that northern Vietnamese sea has very wide shelfs associated with very gentle sloping foreshores in order to find out the change of spectral wave periods over this long distance.

Here Table 1 introduces and defines the parameters that are used in the section below.

\begin{tabular}{|c|c|c|c|}
\hline $\mathrm{d}$ & wave overtopping thickness [m] & $\mathrm{R}_{\mathrm{u}}$ & wave run-up over a slope [m] \\
\hline $\mathrm{D}_{\mathrm{f}}$ & wave energy dissipation $\left[\mathrm{cm}^{2} / \mathrm{s}\right]$ & $\mathrm{T}_{\mathrm{m}-1,0, \mathrm{o}}$ & $\begin{array}{l}\text { spectral mean wave energy period in } \\
\text { SWASH b.c [s] }\end{array}$ \\
\hline $\mathrm{E}$ & $\begin{array}{l}\text { spectral density of the water surface } \\
\text { elevation }\left[\mathrm{m}^{2} / \mathrm{Hz}\right]\end{array}$ & $\mathrm{T}_{\mathrm{m}-1,0, \mathrm{t}}$ & $\begin{array}{c}\text { spectral mean wave energy period at } \\
\text { toe }[\mathrm{s}]\end{array}$ \\
\hline $\mathrm{f}$ & frequency $\left[\mathrm{s}^{-1}\right]$ & $\mathrm{T}_{\mathrm{P}}$ & peak wave period in SWAN b.c [s] \\
\hline $\mathrm{h}$ & water depth [m] & $\mathrm{U}_{10}$ & wind speed at $10 \mathrm{~m}$ above SWL $[\mathrm{m} / \mathrm{s}]$ \\
\hline$h_{\text {toe }}$ & water depth at dike toe $[\mathrm{m}]$ & $\mathrm{v}$ & wave overtopping velocity $[\mathrm{m} / \mathrm{s}]$ \\
\hline
\end{tabular}

Table 1. Nomenclature used in this paper. 
Table 1. Cont.

\begin{tabular}{|c|c|c|c|}
\hline $\mathrm{H}_{\mathrm{s}}$ & $\begin{array}{l}\text { spectral significant wave height at } \\
\text { SWAN boundary condition (b.c) [m] }\end{array}$ & $\mathrm{U}_{10}$ & wind speed at $10 \mathrm{~m}[\mathrm{~m} / \mathrm{s}]$ \\
\hline $\mathrm{H}_{\mathrm{m} 0}$ & spectral significant wave height [m] & $\mathrm{x}$ & distance $[\mathrm{km}]$ \\
\hline $\mathrm{H}_{\mathrm{m} 0, \mathrm{o}}$ & $\begin{array}{l}\text { spectral significant wave height at } \\
\text { SWASH b.c [m] }\end{array}$ & $\theta$ & foreshore slope in SWASH [degree] \\
\hline $\mathrm{H}_{\mathrm{m} 0, \mathrm{t}}$ & $\begin{array}{l}\text { spectral significant wave height at dike } \\
\text { toe }[\mathrm{m}]\end{array}$ & $\gamma_{\mathrm{f}}$ & $\begin{array}{l}\text { reduction coefficient which includes the } \\
\text { effects of slope roughness [-] }\end{array}$ \\
\hline $\mathrm{k}$ & wave number [-] & $\gamma_{\beta}$ & $\begin{array}{l}\text { reduction coefficient which includes the } \\
\text { effects of obliqueness [-] }\end{array}$ \\
\hline q & $\begin{array}{l}\text { wave overtopping discharge per meter } \\
\text { width of structure }\left[\mathrm{m}^{3} / \mathrm{s} / \mathrm{m}\right]\end{array}$ & $\alpha$ & dike slope in seaward [degree] \\
\hline $\mathrm{R}_{\mathrm{c}}$ & crest freeboard $[\mathrm{m}]$ & $\delta$ & $\begin{array}{l}\text { equivalent slope in shallow foreshore } \\
\text { [degree] }\end{array}$ \\
\hline & & $\xi_{\mathrm{m}-1,0}$ & Irribaren number [-] \\
\hline
\end{tabular}

\subsubsection{Bathymetry}

Apart from the very central Vietnamese coast, typical Vietnamese cross-shore bathymetries exhibit very gentle and smooth bed slopes due to the large shelf widths (Figure 1). These wide shelves create a relatively long distance for wave energy transformation and dissipation or wind generation. Typical bathymetries show that the depth contours are parallel so 1D models can appropriately be applied. From a water depth of less than $20 \mathrm{~m}$ to the nearshore, the foreshore slope is roughly 1:500 (Figure 2). To derive characteristic wave conditions a typical storm for this area is simulated.

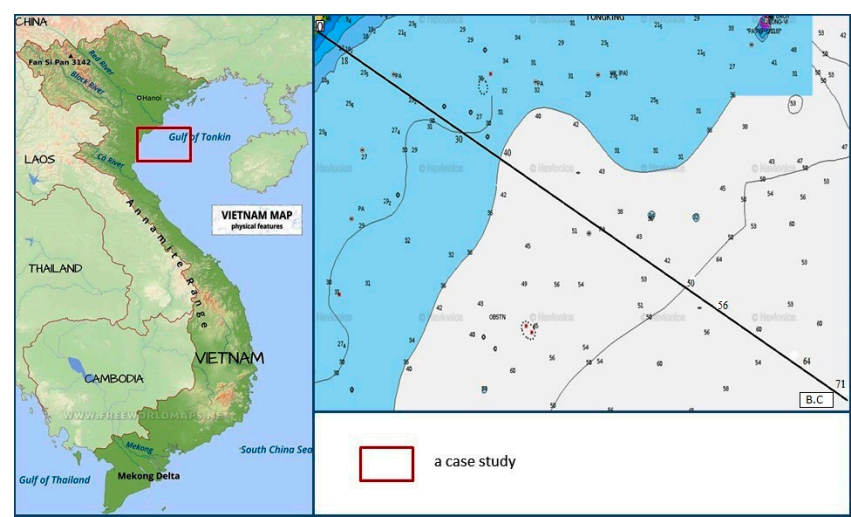

(a)

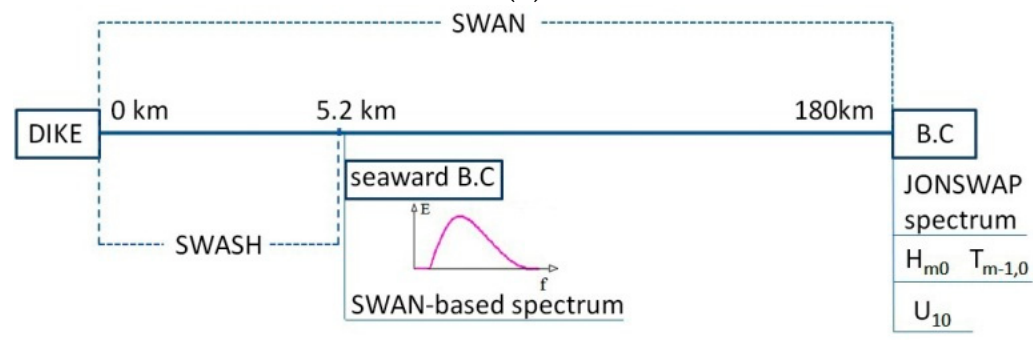

Figure 1. (a) A case study on the Vietnamese coastlines (top-left figure) and corresponding bathymetry (top-right figure), depths are indicated in meters. (b) Boundary conditions of SWAN and SWASH models (bottom figure). 

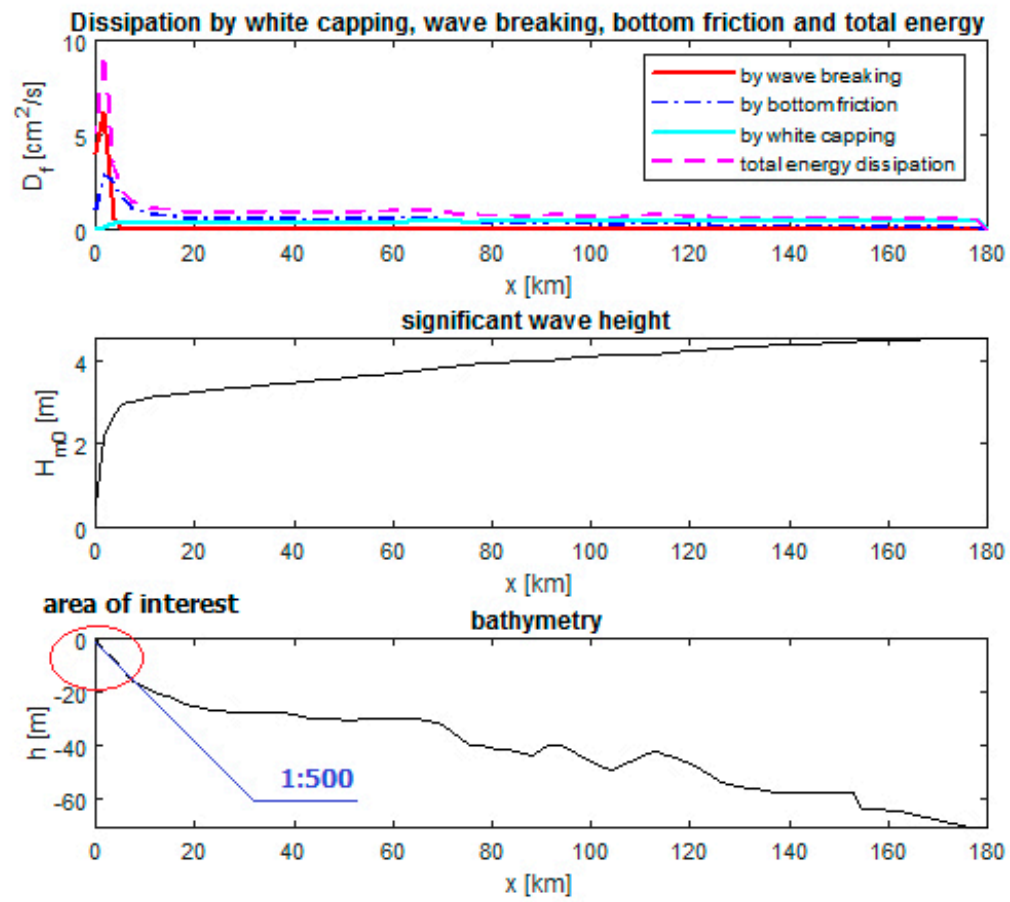

Figure 2. Wave dissipation, significant wave height calculated by SWAN, and bathymetry of the north site with the interested area.

\subsubsection{Offshore Hydraulic Conditions and Dike Geometries}

An accurate prediction of the wave transformation from offshore to dike toes is of great importance for coastal areas. The transformation of wave spectra across the cross-shore water areas with wind growth was taken into account. Due to very gently sloping foreshore with a very wide coastal shelf, the wind generation could not be ignored. Moreover, the very wide coastal shelf leads to fully developed sea, so wave parameters will be following the maximum condition according to Figures 3-23 in [16].

Input offshore wave parameters for the SWAN model used are as follows: $H_{\mathrm{s}}=4.5 \mathrm{~m}, \mathrm{~T}_{\mathrm{P}}=11 \mathrm{~s}$, $\mathrm{U}_{10}=12 \mathrm{~m} / \mathrm{s}$, for a 10-year return period according to Vietnamese condition [17]. The offshore hydraulic boundary is located at level $-70 \mathrm{~m}$ whereas landward boundary lies at $+0 \mathrm{~m}$. Computational domain has been defined on a regular grid size of $100 \mathrm{~m}$ in a total length of $180 \mathrm{~km}$. At the shoreward boundary a closed boundary is imposed. Wind and wave directions are assumed to be perpendicular to the coastline, as this is the most conservative condition. Extreme water levels, based on a high spring tide and storm surge, are roughly $3 \mathrm{~m}$.

Dike crest is $5 \mathrm{~m}$ with a seaward slope of 1:4. These parameters will be investigated to determine the overtopping discharges for very shallow water later on.

One more case will be considered as follows when a high sandy foreshore is nourished as have being done on the Dutch and Belgian coasts, the water level at the toe is $1.5 \mathrm{~m}$.

\subsubsection{Wave Dissipation without Sea Dikes}

The purpose of this section is to emphasize that this foreshore is due to a very wide shelf over a long cross-shore trajectory, and therefore the wind effect needs to be included. Moreover, since wind generation is excluded in SWASH, SWAN is an alternative and appropriate model to use over this long distance.

A constant wind is blowing over deep water, developing an internal atmospheric boundary layer starting at the boundary. Initially, the wind growth is equal to wave dissipation, so the wave height more or less stays the same after roughly $50 \mathrm{~km}$ seaward before decreasing gradually. When the wave 
starts to "feel" the bottom, bottom friction increases and significant wave height suddenly decreases until wave breaking, then the wave height rapidly reduces. For mild bottom slopes, the breaking point will lie far from the shore.

\subsection{SWASH Setup}

It was shown in Section 2.1 that away from the coast wind generation plays an important role. Closer to the coast, infragravity waves and surfzone wave breaking will have a significant role, which is not, or not sufficiently, incorporated in the SWAN model. Hence, for the near shore region the SWASH model is applied in order to obtain the wave period and overtopping at a very gentle sloping coastal profile. The wave spectra from the SWAN calculation results shown above are used as boundary conditions for the SWASH model. The SWASH model is developed based on non-linear shallow water equations with a non-hydrostatic pressure model. It is a time domain model for simulating a non-hydrostatic, free-surface, and rotational flow, including short waves $[3,18]$. The smaller the grid dimension gets, the more exact the model becomes; however, it consumes a longer calculation time. The non-hydrostatic pressure is used for Keller-box scheme which will be mainly applied for accurate wave transformation. A JONSWAP wave spectrum with $\gamma=3.3$ is used for numerical model. A default Manning's roughness coefficient of 0.019 is used for all calculations.

\subsubsection{Configuration to Determine Spectral Wave Period at Dike Toes}

The spectral wave period of incident waves at the toes is a crucial parameter to determine the mean overtopping discharge over sea-dikes as mentioned in Section 1.1. In order to determine the spectral wave period and wave height corresponding to the incoming wave signal, the setup as given in Figure 3 is applied. In this way the reflection of the waves from the dike is not influencing the signal. Because the sloping bed foreshore is very mild, wave reflection is expected to be insignificant.

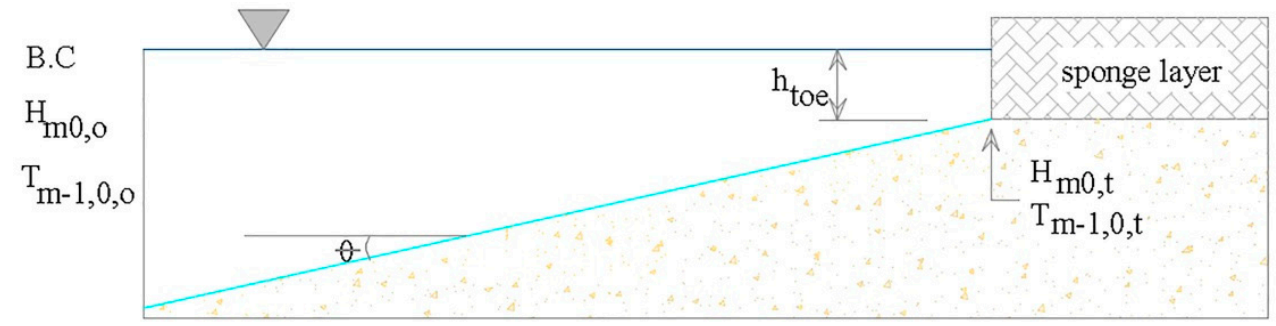

Figure 3. Wave parameters at toes in SWASH model for case studies.

In the SWASH calculation the water depth at the offshore boundary condition is taken to be more than 4 times the corresponding significant wave height. Sponge layers are used at the SWASH open boundaries to effectively absorb the wave energy. The sponge layer length is often taken as 3 to 5 times the wavelength at the offshore boundary and schematized by one vertical layer [19]. The sponge layer had a length of $1000 \mathrm{~m}$ from the dike toe for the foreshore slope of 1:500. For all cases in Sections 3.1-3.4 below, the grid size of the bathymetry is adopted as $1 \mathrm{~m}$ and time duration is approximately $1 \mathrm{~h}$; however, for the wave overtopping discharge calculations, from Sections 3.5-3.8, the grid size is smaller and the time duration is much longer, $0.2 \mathrm{~m}$ and $8 \mathrm{~h}$, respectively. Time step of the numerical simulations is changed flexibly due to Courant-Friedrichs-Lewy (CFL) requirement [19].

In the calculations, the same wave parameters $H_{m 0,0}=3 \mathrm{~m}$ and $T_{m-1,0}=11 \mathrm{~s}$ as obtained from the SWAN calculation at the start of the surf zone $(x=5.2 \mathrm{~km}$ in Figure 2$)$ were applied for different foreshore slopes in Table 2 as follows: 
Table 2. SWASH input data for different slopes and water depths (no structure).

\begin{tabular}{cccc}
\hline Slope & $\begin{array}{c}\mathbf{h} \\
{[\mathbf{m}]}\end{array}$ & $\begin{array}{c}\mathbf{x} \\
{[\mathbf{k m}]}\end{array}$ & $\begin{array}{c}\mathbf{h}_{\text {toe }} \\
{[\mathbf{m}]}\end{array}$ \\
\hline 35 & 12.5 & 385 & 1.5 \\
100 & 12.5 & 1100 & 1.5 \\
250 & 12.5 & 2750 & 1.5 \\
500 & 12.5 & 5200 & 1.5 \\
700 & 12.5 & 7700 & 1.5 \\
800 & 12.5 & 8800 & 1.5 \\
900 & 12.5 & 9900 & 1.5 \\
1000 & 12.5 & 11,000 & 1.5 \\
\hline 35 & 13.2 & 385 & 2.2 \\
100 & 13.2 & 1100 & 2.2 \\
250 & 13.2 & 2750 & 2.2 \\
500 & 13.2 & 5200 & 2.2 \\
700 & 13.2 & 7700 & 2.2 \\
800 & 13.2 & 8800 & 2.2 \\
900 & 13.2 & 9900 & 2.2 \\
1000 & 13.2 & 11,000 & 2.2 \\
\hline 35 & 14 & 385 & 3 \\
100 & 14 & 1100 & 3 \\
250 & 14 & 2750 & 3 \\
500 & 14 & 5200 & 3 \\
700 & 14 & 7700 & 3 \\
800 & 14 & 8800 & 3 \\
900 & 14 & 9900 & 3 \\
1000 & 14 & 11,000 & 3 \\
\hline
\end{tabular}

\subsubsection{Configuration to Determine Overtopping of the Sea Dike}

The "virtual" overtopping discharge q-approximated by using a straight long slope and deriving the discharge exceeding the elevation of $R_{C}$ (Figure 4)—will be determined efficiently for many $R_{C}$ using a straight long slope. To verify the assumption that this yields the correct $\mathrm{q}$, a realistic dike with fixed $R_{C}$ is used. The same boundary conditions are applied for an infinite slope and a realistic sea dike to calculate the wave overtopping discharge based on water velocities and thicknesses for a shallow foreshore. The boundary conditions in the SWASH model are wave height and period from the SWAN model, assuming a JONSWAP spectral shape. The simulation duration for the wave overtopping model is advised to be at least 1000 waves [20-22]. If LF waves are considered to play an important role at the toe of the dike, wave overtopping durations need 1000 LF waves, or roughly 5000 primary waves. In the calculations, duration is applied equivalent to more than 700 times wave periods. The duration of a calculation on a regular PC is approximately $8 \mathrm{~h}$ for one simulation. In SWASH, the bathymetry is calculated every $0.2 \mathrm{~m}$, time steps are $0.05 \mathrm{~s}$, as well and one layer applied. The calculation is based on a linearly sloping and impermeable seabed.

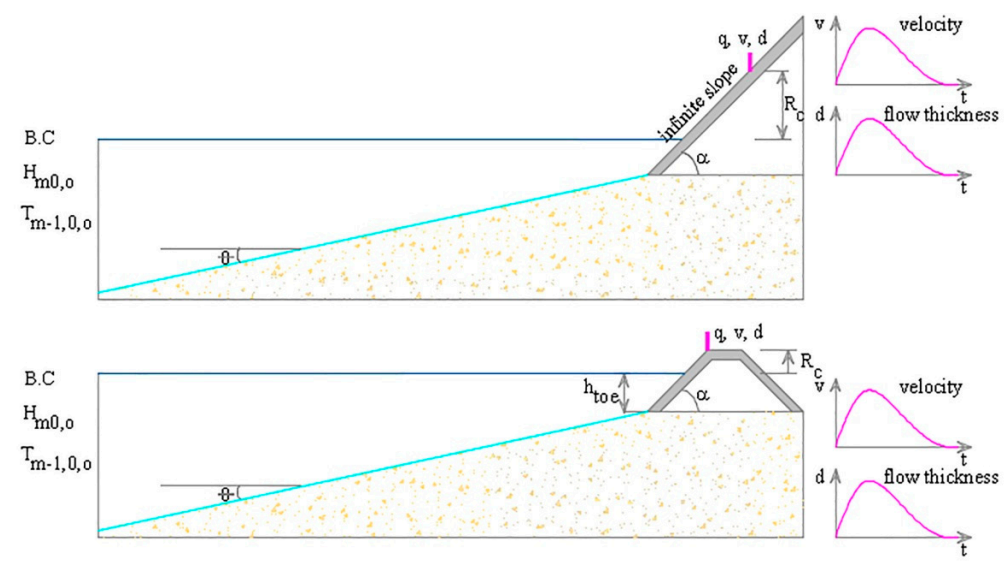

Figure 4. Wave overtopping over an infinite slope and a real sea dike. 
From the SWASH model a time series obtained of the wave overtopping velocities and thicknesses on the dike are originated at the dike crest (corresponding to lower Figure 4). The overtopping discharges are calculated based on wave overtopping velocities $\mathrm{v}$ and layer thicknesses $\mathrm{d}$ at the outer crest line as follows:

$$
\mathrm{q}(\mathrm{t})=\mathrm{d}(\mathrm{t}) \mathrm{v}(\mathrm{t})
$$

Mean wave overtopping discharge is determined by integrating $q(t)$ for $q(t)>0$, over the duration, whereas $t_{\text {start,i }}$ and $t_{\text {end,i }}$ are start and end time of the wave overtopping predictions, respectively.

$$
V_{i}=\frac{\int_{t_{s t a r t, i}}^{t_{\text {end }, i}} q(t) d t}{t_{\text {end,i }}-t_{\text {start,i }}}
$$

For a straight seaward high slope (corresponding to upper Figure 4), the instantaneous virtual wave overtopping discharge $\mathrm{q}(\mathrm{t})$ is also similarly predicted as the Equation (9) at any elevations of the seaward slope, following Hofland [23]. Hence, this computation is very efficient to obtain the overtopping discharge for many dike freeboards.

\subsubsection{Mean Wave Overtopping Discharge over the Dike Crest}

Simultaneously, similar boundary conditions are applied in the formulae of Van Gent [4] and Altomare [5], using Hofland [11] to compare the relation between the incoming waves overtopping discharge for a very shallow foreshore. Two cases are considered, with the same offshore boundary conditions but different water depths (see Table 3). The mean wave overtopping discharges will be calculated with a variety of different crest freeboards, as described in the previous section (or dike crest heights) in numerical models, and these predicted means will be compared with the existing empirical formulae referred to above. According to these formulae, q will demonstrate in exponential form, which is characterized by incoming wave height and spectral period at the toe of sea-dike, foreshore, and sea-dike geometries.

Table 3. Two cases of wave overtopping discharge for the Vietnamese slope calculated.

\begin{tabular}{cccccccc}
\hline \multirow{2}{*}{ Slope } & \multicolumn{6}{c}{ SWAN } & \multicolumn{5}{c}{ SWASH } \\
\cline { 2 - 8 } & $\begin{array}{c}\mathbf{H}_{\mathbf{m} \mathbf{0} \mathbf{0}} \\
{[\mathbf{m}]}\end{array}$ & $\begin{array}{c}\mathbf{T}_{\mathbf{P}} \\
{[\mathbf{s}]}\end{array}$ & $\begin{array}{c}\mathbf{U}_{\mathbf{1 0}} \\
{[\mathbf{m} / \mathbf{s}]}\end{array}$ & $\begin{array}{c}\mathbf{x} \\
{[\mathbf{k m}]}\end{array}$ & Boundary Condition & $\begin{array}{c}\mathbf{h}_{\text {toe }} \\
{[\mathbf{m}]}\end{array}$ & $\begin{array}{c}\mathbf{x} \\
{[\mathbf{k m}]}\end{array}$ \\
\hline 500 & 4.5 & 11 & 12 & 180 & JONSWAP spectra & 1.5 & 5.2 \\
\hline 500 & 4.5 & 11 & 12 & 180 & JONSWAP spectra & 3 & 5.2 \\
\hline
\end{tabular}

\section{Results}

\subsection{Wind Influence on Wave Transformation}

The SWAN calculation in Section 2.1 indicates that the wind impact on very shallow foreshores with wide shelves cannot be ignored. Hereafter, this study will find out an appropriate distance to start the SWASH calculation, on which wind has limited impacts. The effect of wind on wave heights was considered with different speeds in several kilometers. The wind speeds $\mathrm{U}_{10}$ were 0,12 , and $25 \mathrm{~m} / \mathrm{s}$, respectively. Calculations were made with $5200 \mathrm{~m}$ length between boundary condition and the shoreline, the foreshore slope was roughly 1:500. The results are shown in Figure 5, where $x=0$ represents the coastline. The difference between wave heights at the coast with, or without, wind input was negligible in case of no, and $12 \mathrm{~m} / \mathrm{s}$, wind speeds. The $25 \mathrm{~m} / \mathrm{s}$ wind showed the different results in wave heights around $2 \mathrm{~km}$ away from the shore. Therefore, the wind did not seem to have any influence on wave transformation within several kilometers if the wind speed was $12 \mathrm{~m} / \mathrm{s}$, or where the $12 \mathrm{~m} / \mathrm{s}$ wind was more applicable for this distance. Hereafter, a distance of $5200 \mathrm{~m}$ with a 
wind speed of $12 \mathrm{~m} / \mathrm{s}$ will be used to calculate wave parameters and wave overtopping in SWASH without wind effect.

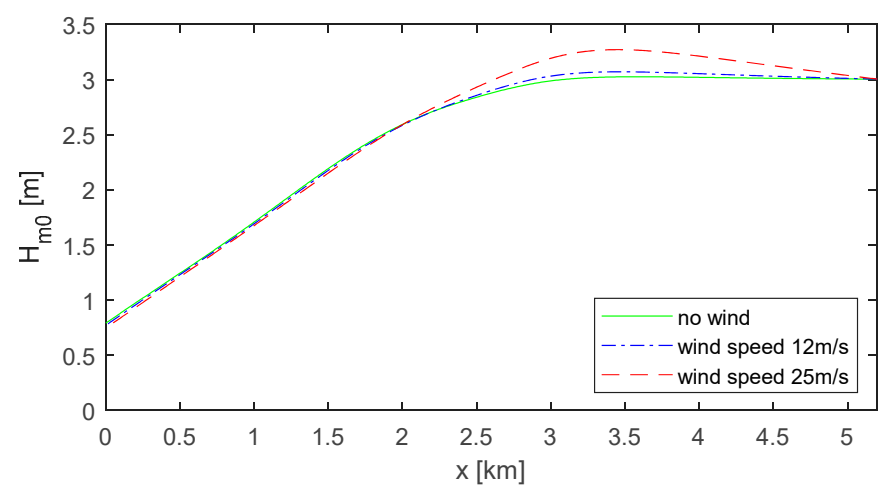

Figure 5. Wind effect on wave heights in SWAN for slope 1:500.

\subsection{Wave Heights and Periods at the Toes of Sea Dikes}

Here, the behavior of wave parameters in the nearshore area for both the SWAN and SWASH calculations is inspected. The same boundary conditions were applied in these models. Wave parameters were both JONSWAP wave spectrum, corresponding to $\mathrm{H}_{\mathrm{m} 0}=3 \mathrm{~m}, \mathrm{~T}_{\mathrm{m}-1,0}=11 \mathrm{~s}$. The most important parameters are plotted in Figure 6, noticing that high-frequency (HF) and low-frequency (LF) waves were estimated by SWASH. For very gently sloping foreshores, waves seemed to be dissipated over a long distance from offshore to the toes of the dikes, while reflected waves were expected to be minimal over these foreshores. $\mathrm{H}_{\mathrm{m} 0}$ was somewhat higher for SWAN compared to that of SWASH for distances from shore of $\mathrm{x}=2$ to $5.2 \mathrm{~km}$. This was possibly caused by the extra wind input in the SWAN calculation.
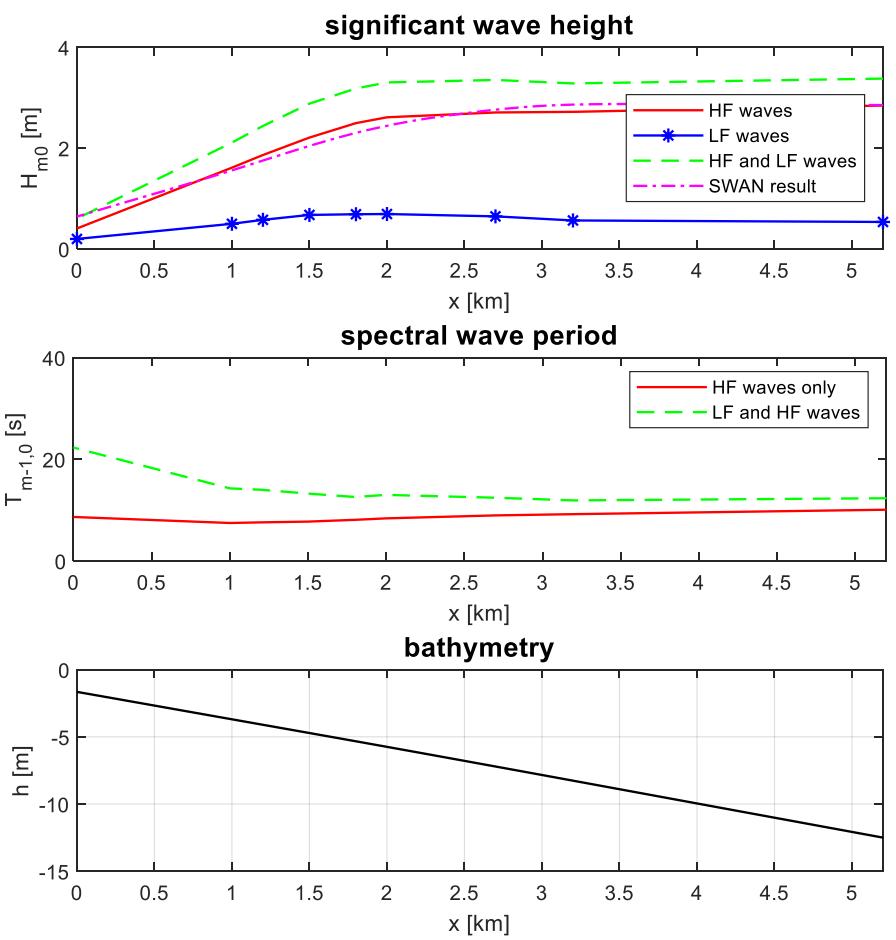

Figure 6. SWAN and SWASH results for 1:500 slope. 
Both HF and LF waves started breaking when they reached the shallow zone. However, the HF waves started breaking earlier than the LF waves, around the distance of $2 \mathrm{~km}$ from nearshore, as the LF waves were mainly generated mainly when the HF waves were breaking. The LF waves broke corresponding to a distance of roughly $1.5 \mathrm{~km}$ (see the top of Figure 6). After the start of breaking, HF waves decreased linearly, whereas LF waves decreased gradually when reaching the shore.

To investigate further the wave periods $\mathrm{T}_{\mathrm{m}-1,0}$, according to the red line on the spectral wave period curve in Figure 6, they stayed more or less unchanged from offshore to surf zone. After wave breaking, LF waves became dominant over the HF waves. Waves with a lower steepness broke closer to the shore and LF waves occurred in SWASH, so waves from SWAN broke further than those in SWASH to the shore.

\subsection{Wave Spectra Over the Shallow Foreshore}

Here, the near shore spectra as obtained from SWASH for this case are presented. It can be noticed that the wave spectra, shown by red thick lines in Figure 7, not only vary their total amount of variance (i.e., wave energy), but also their shape. On a shallow foreshore, due to the process of triad wave-wave interaction, the wave spectral peak constantly migrated towards the lower frequencies; therefore, the wave spectral shape became flattened, completely different from JONSWAP in the offshore. This flattened shape has been investigated based on previous research on shallow foreshore $[6,20]$.
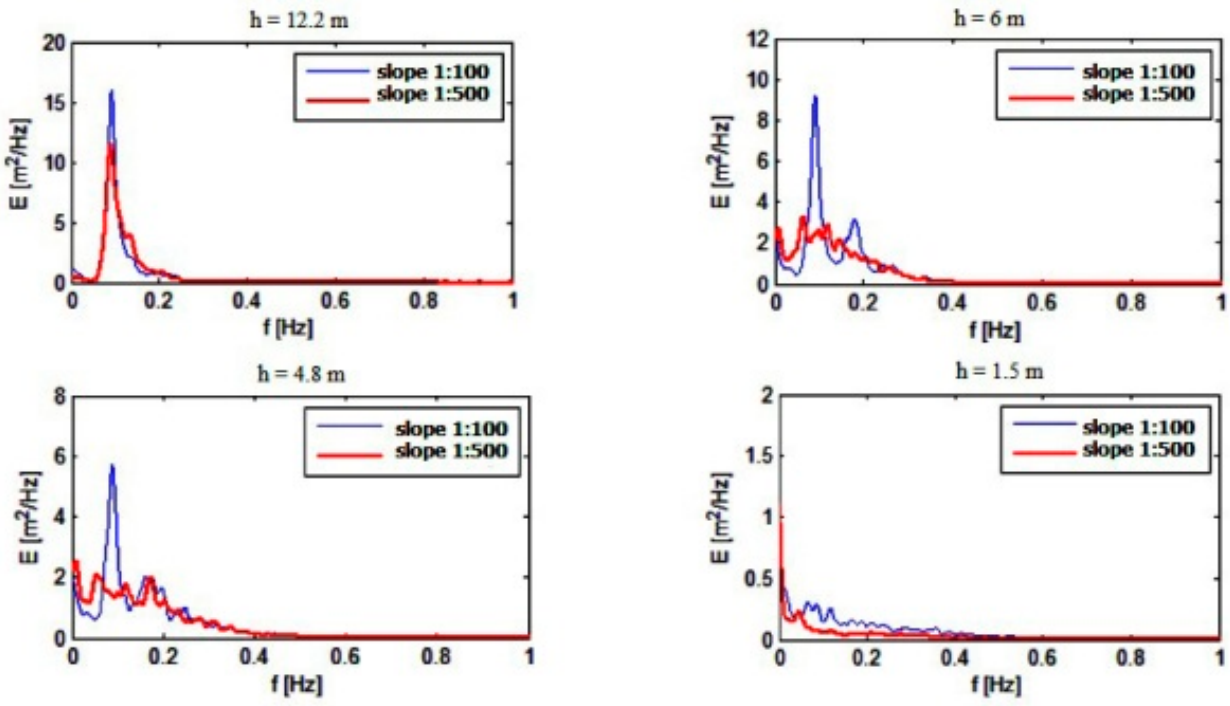

Figure 7. Wave spectra calculated by SWASH over the distance for a steeper slope 1:100 (blue thin line) and a very gentle slope 1:500 (red thick line), at several equal water depths (note the varying vertical scaling).

From the offshore boundary conditions in SWASH, the wave energy started to decrease due to increased wave dissipation. Additionally, the energy redistribution occurred because of triad wave-wave interaction, which explains the presence of other peaks around frequencies twice, and four times, the peak frequency. From a certain depth, the energy of HF waves whose frequencies were more than $0.05 \mathrm{~Hz}$ dissipated and more energy occurred in low frequencies. The LF wave energy, at frequencies between $0.005 \mathrm{~Hz}$ to $0.05 \mathrm{~Hz}$, increased from depths between 10 and $6 \mathrm{~m}$, and subsequently seemed to be more or less constant up to depths of $2.5 \mathrm{~m}$, so the LF waves increased relatively compared to the HF waves.

There is a significant difference when comparing wave spectra between very gentle slope and steeper slope (1:100 as blue thin lines in the Figure 7) at the same water depths. The primary waves were more at the gentler slope, as the peak of the primary wave $(\mathrm{f} \approx 0.1 \mathrm{~Hz})$ decreased faster. This is probably explained by the fact that a change in depth corresponds to a longer distance such that 
the waves have more time to break. On the shallow foreshore, both slopes had increased LF energy. The LF energy level between depths of 6 and $2.5 \mathrm{~m}$ was higher for the very gentle 1:500 slope.

Additionally, at the original water line $(\mathrm{h}=0 \mathrm{~m})$, there was wave energy due to the set-up of the water level that was not included in $h$. Here, the 1:100 slope still exhibited much more HF energy.

\subsection{Spectral Wave Periods at Gentle to Very Gentle Slopes}

Here, the evolution of spectral wave periods $\mathrm{T}_{\mathrm{m}-1,0, t}$ at the dike toe is investigated, compared with those in offshore, as calculated with SWASH. The spectral wave periods are presented relative to the offshore wave parameters and water depths. In Table 4 below, these predictions are compared with those in Hofland [11], which were derived for this range of slope angles.

Table 4. A comparison of spectral wave period between Hofland [11] and SWASH results. These are shallow to very shallow conditions according to the Hofland [11] classification, where the ratio $\frac{\mathrm{T}_{\mathrm{m}-1,0, t}}{\mathrm{~T}_{\mathrm{m}-1,0, \mathrm{o}}}$ from the curve indicates the range $\pm 2 \sigma$ for error bands.

\begin{tabular}{|c|c|c|c|c|c|c|c|}
\hline \multirow[b]{2}{*}{$\cot \theta$} & \multicolumn{6}{|c|}{ SWASH Results } & \multirow{2}{*}{$\begin{array}{c}\text { Hofland [8] } \\
\frac{T_{m-1,0, t}}{T_{m-1,0,0}}\end{array}$} \\
\hline & $\begin{array}{c}\mathbf{H}_{\mathrm{m} 0, \mathbf{o}} \\
{[\mathrm{m}]}\end{array}$ & $\begin{array}{c}\mathrm{T}_{\mathrm{m}-1,0, \mathrm{o}} \\
{[\mathrm{s}]}\end{array}$ & $\underset{[s]}{T_{m-1,0, t}}$ & $\frac{\mathbf{T}_{\mathbf{m}-1,0, \mathbf{t}}}{\mathbf{T}_{\mathbf{m}-1,0, \mathbf{0}}}$ & $\mathbf{h}_{\text {toe }}$ & $\frac{\mathbf{h}_{\text {toe }}}{\mathbf{H}_{\mathrm{m} 0, \mathbf{o}}}\left(\frac{\cot \Theta}{100}\right)^{0.2}$ & \\
\hline 35 & 3 & 11 & 20.4 & 1.9 & 1.5 & 0.4 & $2.7 \pm 0.8$ \\
\hline 100 & 3 & 11 & 23.8 & 2.2 & 1.5 & 0.5 & $2.5 \pm 0.7$ \\
\hline 250 & 3 & 11 & 26 & 2.4 & 1.5 & 0.6 & $2.2 \pm 0.6$ \\
\hline 35 & 3 & 11 & 21.5 & 2 & 2.2 & 0.6 & $2.2 \pm 0.6$ \\
\hline 100 & 3 & 11 & 22.6 & 2.1 & 2.2 & 0.7 & $2.0 \pm 0.4$ \\
\hline 250 & 3 & 11 & 19.8 & 1.8 & 2.2 & 0.9 & $1.6 \pm 0.4$ \\
\hline 35 & 3 & 11 & 13.3 & 1.2 & 3 & 0.8 & $1.8 \pm 0.4$ \\
\hline 100 & 3 & 11 & 14 & 1.3 & 3 & 1 & $1.5 \pm 0.4$ \\
\hline 250 & 3 & 11 & 13.4 & 1.2 & 3 & 1.2 & $1.4 \pm 0.4$ \\
\hline 500 & 3 & 11 & 25 & 2.3 & 1.5 & 0.7 & $2.0 \pm 0.4$ \\
\hline 700 & 3 & 11 & 25.4 & 2.3 & 1.5 & 0.7 & $2.0 \pm 0.4$ \\
\hline 800 & 3 & 11 & 28.4 & 2.6 & 1.5 & 0.8 & $1.8 \pm 0.4$ \\
\hline 900 & 3 & 11 & 33.3 & 3.0 & 1.5 & 0.8 & $1.8 \pm 0.4$ \\
\hline 1000 & 3 & 11 & 39 & 3.5 & 1.5 & 0.8 & $1.8 \pm 0.4$ \\
\hline 500 & 3 & 11 & 22.1 & 2 & 2.2 & 1 & $1.5 \pm 0.4$ \\
\hline 700 & 3 & 11 & 22.3 & 2 & 2.2 & 1.1 & $1.4 \pm 0.3$ \\
\hline 800 & 3 & 11 & 24 & 2.2 & 2.2 & 1.1 & $1.4 \pm 0.3$ \\
\hline 900 & 3 & 11 & 22.6 & 2.1 & 2.2 & 1.1 & $1.4 \pm 0.3$ \\
\hline 1000 & 3 & 11 & 24.5 & 2.2 & 2.2 & 1.2 & $1.4 \pm 0.3$ \\
\hline 500 & 3 & 11 & 20.5 & 1.9 & 3 & 1.4 & $1.3 \pm 0.2$ \\
\hline 700 & 3 & 11 & 18 & 1.6 & 3 & 1.5 & $1.2 \pm 0.2$ \\
\hline 800 & 3 & 11 & 18 & 1.6 & 3 & 1.5 & $1.2 \pm 0.2$ \\
\hline 900 & 3 & 11 & 18.5 & 1.7 & 3 & 1.6 & $1.2 \pm 0.2$ \\
\hline 1000 & 3 & 11 & 20 & 1.8 & 3 & 1.6 & $1.2 \pm 0.2$ \\
\hline
\end{tabular}

The calculated evolution of the wave period $T_{m-1,0, t}$ is plotted in Figure 8, as a function of the relative water depth. It is obvious that the spectral wave periods at the dike toe increase when dimensionless depth decreases. It is also seen that compared to slopes up to 1:700, the wave period at low water depth $\left(\frac{h_{\text {toe }}}{\mathrm{H}_{\mathrm{m} 0, \mathrm{o}}}=0.5\right)$, the spectral energy wave period is increased more. 


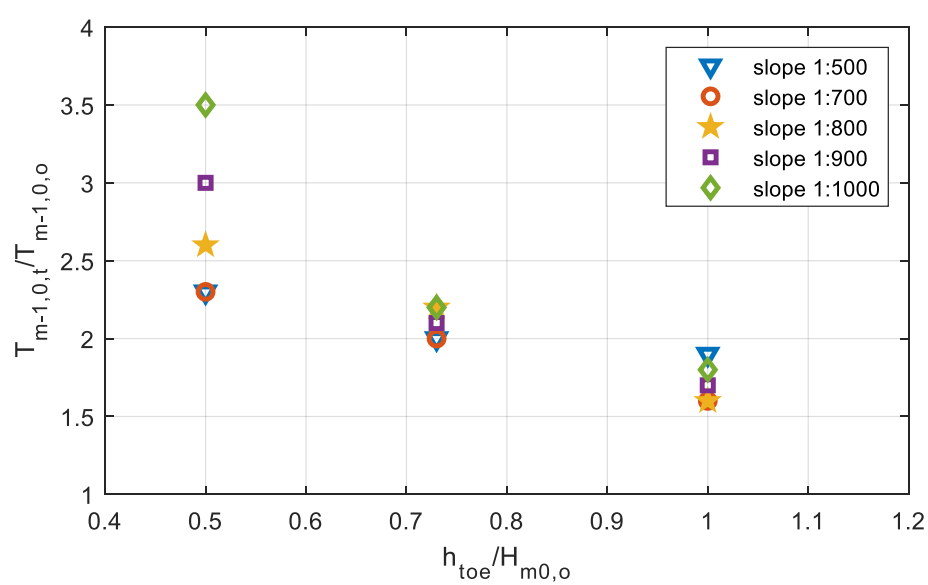

Figure 8. Calculated evolution of spectral wave period $\mathrm{T}_{\mathrm{m}-1,0, \mathrm{t}}$ as a function of water depth, offshore wave height and period.

\subsection{Wave Overtopping Discharge for a Gentle Foreshore Slope}

Here, the mean wave overtopping, still the most used design variable for dike heights, is inspected. First of all, the wave overtopping discharge was calculated for a steeper slope of 1:100, which is in the range of previous studies. The offshore boundary condition in SWASH was again $\mathrm{H}_{\mathrm{m} 0, \mathrm{o}}=3 \mathrm{~m}, \mathrm{~T}_{\mathrm{m}-1,0, \mathrm{o}}$ $=11 \mathrm{~s}$, now at the distance $1100 \mathrm{~m}$ to the dike toe. The dike slope was 1:4, the crest freeboards applied were $2 \mathrm{~m}, 3.25 \mathrm{~m}$, and $4.5 \mathrm{~m}$, respectively. Compared with Altomare's formula [5], the SWASH-based overtopping discharges were very comparable to the formulae (see Figure 9).

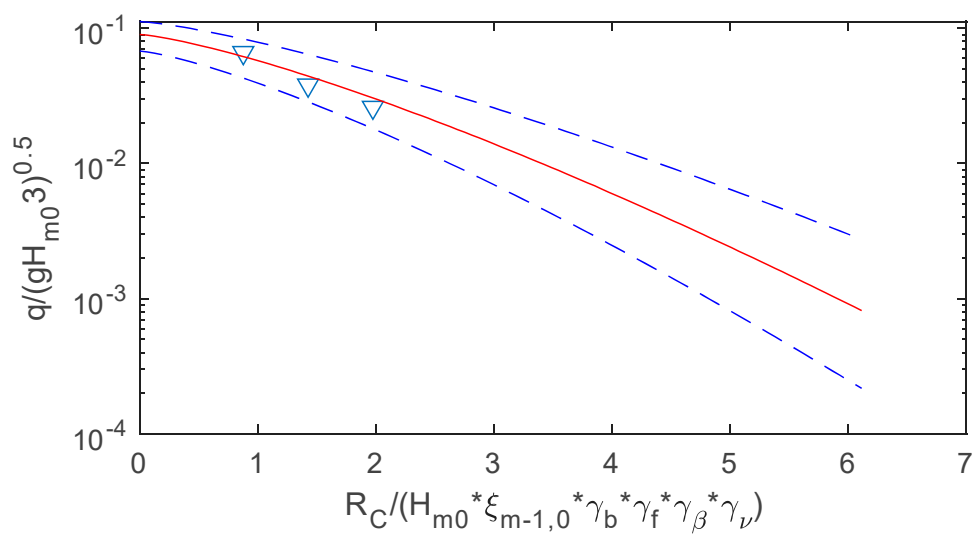

Figure 9. Comparison to Altomare [5] (red solid line: prediction using mean value approach of Altomare; dashed line: $\pm 1.64 \sigma$; and triangle: SWASH values).

\subsection{Wave Overtopping Discharge for Vietnamese Conditions with Very Gentle Slopes}

Now, the typical Vietnamese condition is considered in this section. A SWAN-based JONSWAP wave spectrum was the SWASH boundary, corresponding to $\mathrm{H}_{\mathrm{m} 0, \mathrm{o}}=3 \mathrm{~m}$ and $\mathrm{T}_{\mathrm{m}-1,0, \mathrm{o}}=11 \mathrm{~s}$, at a distance of $5.2 \mathrm{~km}$ from the dike toe. The foreshore slope was roughly 1:500 whereas the seaward dike slope was $\tan \alpha=1: 4$ and the crest freeboard was $2 \mathrm{~m}$. The water thicknesses, velocities, and overtopping discharges were considered in short term duration as well. The two different cases were predicted as follows with $\mathrm{h}_{\mathrm{toe}} / \mathrm{H}_{\mathrm{m} 0, \mathrm{o}}=0.5$ and 1 , respectively, classified from a shallow to a very shallow foreshore.

For the infinite slope the storm duration was $8 \mathrm{~h}$ as well, leading to 4660 incident waves and 980 overtopping waves (more than $20 \%$ of the waves). The mean overtopping discharge during the 
event was 400 l/s/m. Figure 10 shows the overtopping characteristics (layer thickness depth, velocity, and discharge) for the virtual sea ward crest line of the dike.
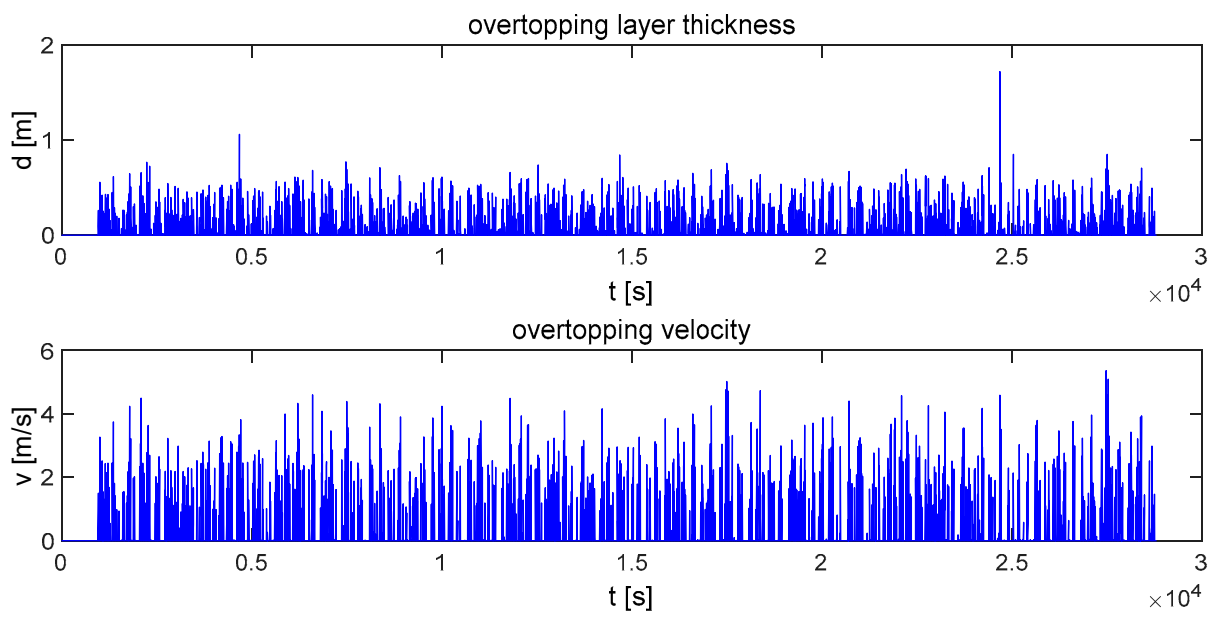

wave overtopping discharge

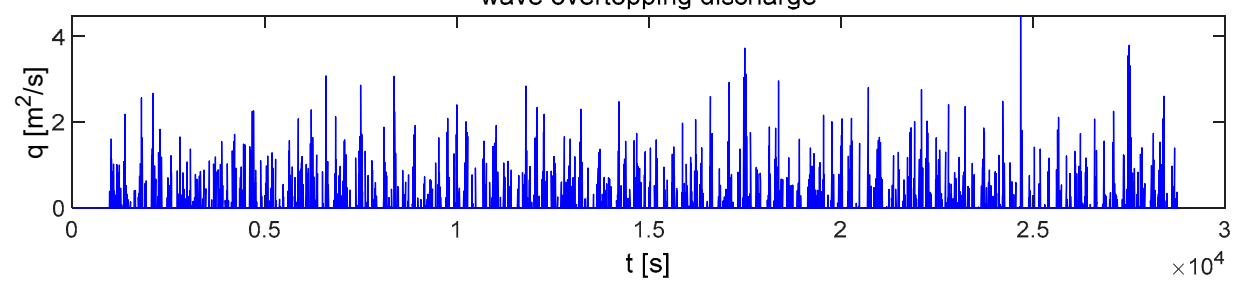

Figure 10. Water thicknesses, velocities, and discharges for the infinite slope.

For the real dike the same wave characteristics were applied. The mean overtopping discharge during the event was $360 \mathrm{l} / \mathrm{s} / \mathrm{m}$.

This overtopping discharge corresponds well to that in the case of the infinite slope. Ten percent difference is not very much for an overtopping discharge. The difference can be explained by the fact that a different realization of the seed values of waves (in SWASH) was used, and that the interaction of reflected and incoming waves was also different in the two cases.

\subsection{Comparison to Existing Approaches}

In this section wave discharges $q$ are calculated for a variety of crest freeboards at the same wave properties at offshore and the toe of sea dike, foreshore slope of 1:500, and a sea dike slope of 1:4 in SWASH, only the freeboard or virtual dike crest was changed every 0.05 in intervals, in the infinite slope model. These SWASH-based overtopping discharges were compared with the existing empirical formulae according to Van Gent [4] and Altomare [5] with 5\% under- and upper-exceedance limits, or $90 \%$ error interval, using the spectral wave period and wave height at the dike toe as calculated by SWASH (see Figure 3) as the input.

The comparison is demonstrated in Figures 11 and 12 by dimensionless overtopping discharge versus relative freeboard. The relative overtopping discharges were plotted using a logarithmic y-axis. It is obvious that the logarithm of relative overtopping rate decreases with the rising relative freeboard.

The red solid line corresponds to the mean value approach of Altomare and Van Gent. The two dashed lines are 90 percent confidence interval of this approach, and the triangles are the SWASH-computed values of the (virtual) overtopping discharge for the infinite slope. 


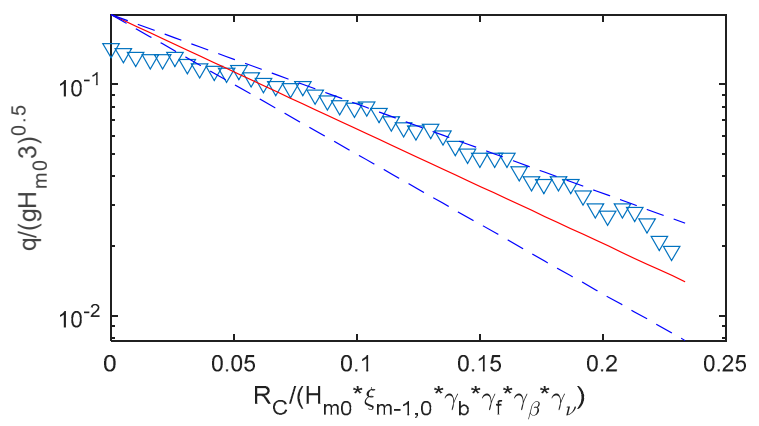

Figure 11. Comparison to Van Gent [4] (red solid line: prediction using mean value approach of Van Gent; dashed line: $\pm 1.64 \sigma$; and triangle: SWASH values).

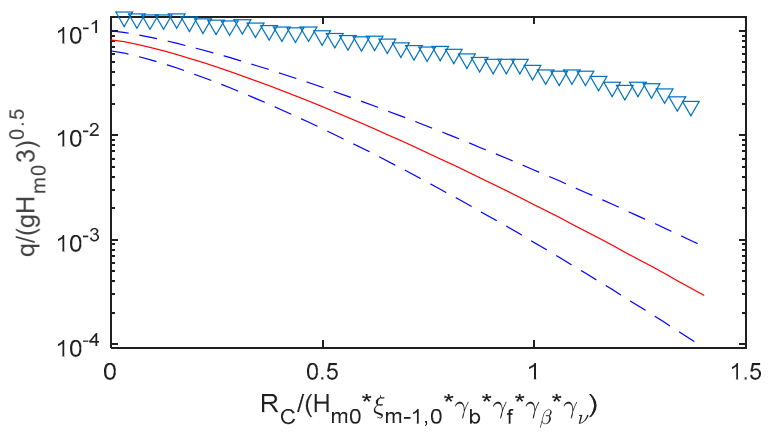

Figure 12. Comparison to Altomare [5] (red solid line: prediction using mean value approach of Altomare; dashed line: $\pm 1.64 \sigma$; and triangle: SWASH values).

From the Figure 11, it is obvious that SWASH gave reliable dimensionless overtopping discharge corresponding to Van Gent's general formulae when the relative freeboard was more than 0.05 . For low values of the dimensionless freeboard, the empirical formulae were overestimated.

However, compared with Altomare's formulae, the SWASH-based values seem to be much higher, especially for high relative freeboards. It is striking that the overtopping discharge hardly seems to decrease with increasing freeboard.

\subsection{Wave Overtopping Discharge for a High Sandy Foreshore}

A high sandy foreshore with the sea dike can be predicted with wave parameters of $\mathrm{H}_{\mathrm{m} 0, \mathrm{o}}=3 \mathrm{~m}$ and $\mathrm{T}_{\mathrm{m}-1,0, \mathrm{o}}=11 \mathrm{~s}$, and water depth at the toe $\mathrm{h}_{\text {toe }}=1.5 \mathrm{~m}$. It was classified as a very shallow water where $0.3<\frac{\mathrm{h}_{\text {toe }}}{\mathrm{H}_{\mathrm{m} 0, \mathrm{o}}}<1$ for infinite slope, and for a real dike (as above description). The foreshore slope was roughly 1:500, whereas the seaward dike slope was $\tan \alpha=1: 4$, and the crest freeboard was $2.5 \mathrm{~m}$.

Additionally, an infinite slope was applied, the storm duration was $8 \mathrm{~h}$ also. Roughly $20 \%$ of the waves, the mean overtopping discharge during the event was $330 \mathrm{l} / \mathrm{s} / \mathrm{m}$. It is striking that even though the water depth was half that of the previous case, and the wave height was also half that of the previous case, the overtopping discharge only decreased by less than $10 \%$. This was probably due to the large increase in LF wave energy.

Now we compare the existing approaches. The more general formulae from Van Gent [4] was used and compared with SWASH-based values. The Figure 13 was valid for low values of $\mathrm{R}_{\mathrm{C}} / \mathrm{H}_{\mathrm{m} 0}\left(0.33+0.022 \xi_{\mathrm{m}-1,0}\right)$, but for higher values of the relative freeboard (more than 0.09$)$, Van Gent's formulae underestimated the mean overtopping rate for this kind of very gently sloping foreshore. 


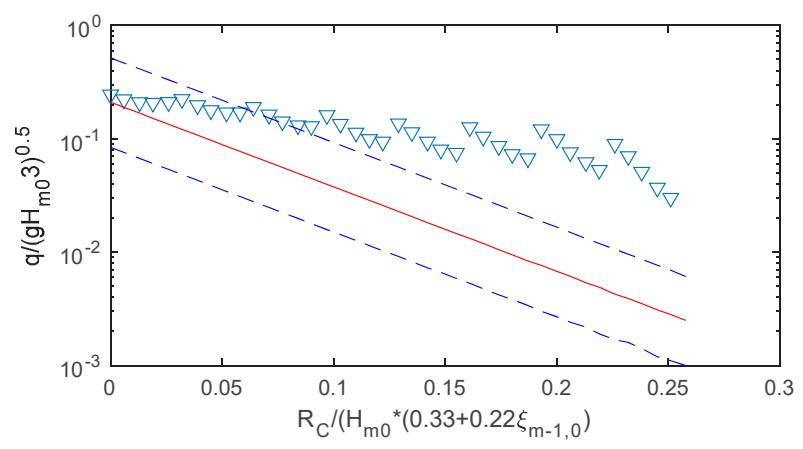

Figure 13. Comparison to Van Gent [4] (red solid line: prediction using mean value approach of Van Gent; dashed line: 5\% under- and upper-exceedance limits; and triangle: SWASH values).

In general, the logarithm of the overtopping rate constantly went down with the increase of the dimensionless freeboard; the plot shows the underestimation of Van Gent's formulae, compared with numerical results. With small values of the freeboard, Van Gent and SWASH-calculated values were relatively appropriate. When the freeboard increased, the Van Gent's formulae lay far from the SWASH-based overtopping discharge.

Further comparison in case of Altomare [5] will be given as follows. It is obvious that the water depth at the toe $h_{\text {toe }}=1.5 \mathrm{~m}$ was larger than $1.5 \mathrm{H}_{\mathrm{m} 0, \mathrm{o}}\left(\mathrm{H}_{\mathrm{m} 0, \mathrm{o}}=0.8 \mathrm{~m}\right.$; see the significant wave height of Figure 6). According to his study, it leads to the calculated Iribarren number $\xi_{\mathrm{m}-1,0}=9.1$ applying the dike slope only; therefore, the equivalent slope $\delta$ in (very) shallow foreshore was not applied in this case. For the above reason, the Altomare's formulae turned into Van Gent's general formulae (Figure 13).

\section{Discussion}

\subsection{Incident Spectral Wave Periods on Gently Sloping Foreshores}

In order to predict wave overtopping over a dike, incident wave parameters at the toe such as $\mathrm{H}_{\mathrm{m} 0}, \mathrm{~T}_{\mathrm{m}-1,0}$ play an important role. Hofland [11], based on data from measurements and calculations for smooth linear foreshores and normal waves, found the evolution of spectral wave period near the toe. The ratio of wave period between offshore condition and extremely shallow waters could rapidly increase, up to about eight times. The bed slope was limited until $\cos \theta=250$. For very gently and straight linear sloping foreshore, such as 1:500, 1:700, 1:800, 1:900, and 1:1000, associated with Table 5, this evolution of short-crested wave period of Hofland [11] seems to be underestimated in the calculated cases for very shallow water (Figure 14).

Table 5. A comparison of various approaches in the shallow water case $\left(\mathrm{h}_{\mathrm{toe}} / \mathrm{H}_{\mathrm{m} 0, \mathrm{o}}=1\right)$.

\begin{tabular}{cccccc}
\hline Parameters & Van Gent [23] & $\begin{array}{c}\text { SWASH and } \\
\text { Altomare [1] }\end{array}$ & $\begin{array}{c}\text { Hofland [8] and } \\
\text { Altomare [1] }\end{array}$ & $\begin{array}{c}\text { SWASH } \\
\text { (Infinite Slope) }\end{array}$ & $\begin{array}{c}\text { SWASH } \\
\text { (Real Dike) }\end{array}$ \\
\hline $\mathrm{H}_{\mathrm{m} 0, \mathrm{o}}[\mathrm{m}]$ & 3 & 3 & 3 & 3 & 3 \\
$\mathrm{~T}_{\mathrm{m}-1,0, \mathrm{o}}[\mathrm{s}]$ & 11 & 11 & 11 & 11 & 11 \\
$\mathrm{~T}_{\mathrm{m}-1,0, \mathrm{t}}[\mathrm{s}]$ & 20.5 & 20.5 & 14 & 20.5 & 20.5 \\
$\xi_{\mathrm{m}-1,0}$ & 4.38 & 0.73 & 0.37 & - & - \\
$\cot \delta[$ degrees] & 0.25 & 0.04 & 0.03 & - & - \\
$\mathrm{q}[\mathrm{l} / \mathrm{s} / \mathrm{m}]$ & 192 & 7 & $\sim 0$ & 400 & 360 \\
\hline
\end{tabular}




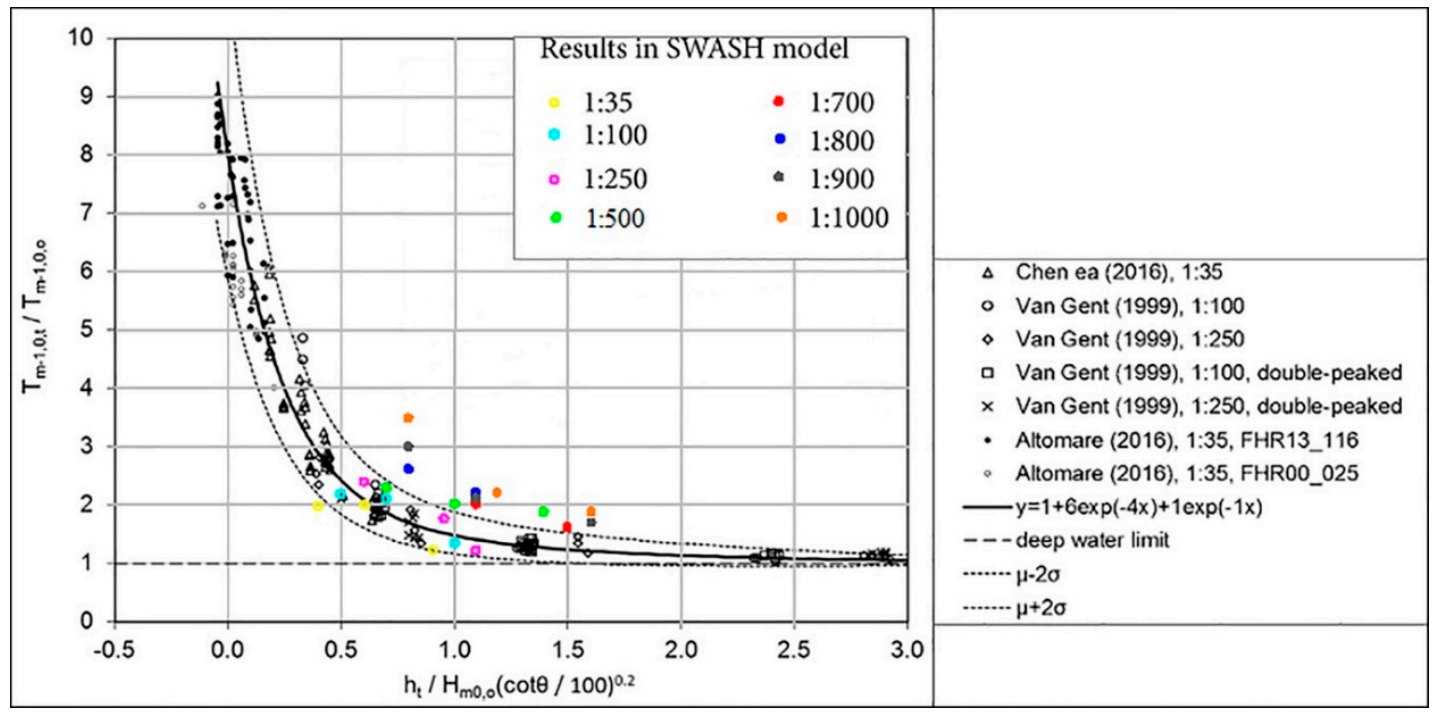

Figure 14. Compare SWASH results for very gently sloping foreshore and evolution of wave period of Hofland [11].

For very gentle and straight linear sloping foreshores as Vietnamese typical bathymetry with slopes more gentle than 1:500, the spectral wave period near the toe of the structures increases more rapidly than for normally gentle slopes.

\subsection{Wave Overtopping Discharge Formulae for Very Gentle Slopes}

As shown in Table 5, it is clear that the mean wave overtopping discharge is more or less the same for the infinite slope and the real dike in very shallow water depths.

In order to predict overtopping discharge over sea-dikes, it is common practice that wave properties at the toe of structures are considered as a key factor. However, according to Altomare [5], in cases where the toe of sea-dikes is located at very shallow water, waves do not actually break on dike slope but on its foreshore. Then the foreshore is considered as "a part" of the sea-dike; therefore, based on this study, wave parameters at the foreshore are precisely crucial instead of those at the toe. An "equivalent slope" concept has been proposed to estimate wave overtopping discharges for shallow and very shallow foreshore. This application is valid for dikes with steep and gentle slopes, $\cot \theta$, less than 250. However, when the foreshores are gentler, like Vietnamese coastlines, "equivalent slope" become smaller and it also makes breaker parameter, $\xi_{\mathrm{m}-1,0}$, much smaller than seven. Therefore, Altomare's empirical formulae are no longer appropriate for these slopes. As shown in Figure 12, Altomare's formulae tend to underestimate the wave overtopping discharge, compared with SWASH-computed values. This new approach is inaccurate for more gently sloping foreshores. More accurate formulae should be derived for this kind of very gentle slopes.

For the formulae of Van Gent [4], the breaker parameter is larger since only the dike slope is included. This prediction seems to be better than the above approach, although, in comparison with SWASH-based values, it also underestimates the overtopping discharge at very shallow water. It needs to have more appropriate formulae for this kind of very mildly sloping and very shallow foreshores. However, the experiments reached their limits in this case due to scale effects for these very gentle slopes, so a numerical approach is the better option.

\section{Conclusions}

Vietnamese guidelines [24] for dike design mainly apply Van Gent [4] to calculate wave overtopping for (very) shallow foreshores, but actually this formula is derived for steep to mild slopes up to slopes of 1:250. Meanwhile, Vietnamese coastlines are characterized by very gently sloping foreshores with 
slopes up to 1:1000 or even more. The process of wave overtopping over the dikes with very gentle slope and shallow foreshore is far from being understood.

This study aims to give a new insight on the wave overtopping over a very gently sloping and shallow foreshore. First, the combination of SWAN (wind influence and no infra-gravity waves) and SWASH (no-wind but infra-gravity waves) proves to be a sufficient model combination for computing wave transformation over this very wide shelf. It is confirmed that shallow water associated with very gently sloping foreshore can cause significant changes of wave spectral shape from offshore to the toes of the dikes. The waves that reach the toe and overtop the dike crest are dominated by LF waves, even more than for less gently sloping beds.

The spectral wave period has been appropriately accepted to predict wave overtopping. Hofland [11], also gives the relationship of spectral wave periods between offshore and the (extremely) shallow water. It is recommended to use within the range of foreshore slope from 20 to 250. For very gently sloping foreshores this spectral wave period near the toe is underestimated, as deduced from numerical model results for various foreshores that are gentler than previous study. The spectral wave period $\mathrm{T}_{\mathrm{m}-1,0}$ for very gentle slopes seems to be approximately two times higher than according to Hofland [11] for very mildly sloping foreshores $(\cot \theta>250)$.

Some further conclusions can be made regarding wave overtopping. It is shown that the infinite slope approach seems to give reasonable overtopping discharges in an efficient manner. At very gentle (and very shallow) foreshores, existing formulae for shallow foreshore overtopping discharge underestimate the wave overtopping discharges $\mathrm{q}$.

A better-founded wave overtopping formula with a shallow and very gently sloping foreshore should be established in physical scale models for more accurate prediction of wave overtopping. This paper is limited to normally incident and long-crested waves, further research is recommended for oblique and/or short-crested waves.

Author Contributions: Conceptualization, T-H.N. and M.S.; methodology, validation, T.-H.N., B.H., and M.S.; software, T.-H.N. and V.D.C.; formal analysis, T.-H.N. and V.D.C.; investigation, resources, V.D.C.; writing - original draft preparation, T.-H.N.; and writing-review and editing, T.-H.N., and B.H. All authors have read and agreed to the published version of the manuscript.

Funding: This study was funded through a Vietnamese governmental scholarship and Delft University of Technology, Delft, The Netherlands, and supported by the National University of Civil Engineering, Hanoi, Vietnam.

Acknowledgments: The authors gratefully acknowledge Tomohiro Suzuki from Flanders Hydraulics Research, Antwerp, Belgium, for giving his advice and checking the model in this study.

Conflicts of Interest: The authors declare no conflict of interest.

\section{References}

1. Bosboom, J.; Stive, M.J.F. Coastal Dynamics I: Lecture Notes CT4305; Delft Academic Press: Delft, The Netherlands, 2015.

2. EurOtop. Manual on Wave Overtopping of Sea Defences and Related Structures-An Overtopping Manual Largely Based on European Research, but for Worldwide Application, 2nd ed.; 2018; Available online: http: //www.overtopping-manual.com/eurotop/downloads/ (accessed on 11 May 2020).

3. Zijlema, M.; Stelling, G.S.; Smit, P.B. SWASH: An operational public domain code for simulating wave fields and rapidly varied flows in coastal waters. Coast. Eng. 2011, 58, 992-1012. [CrossRef]

4. Van Gent, M.R.A. Physical Model Investigations on Coastal Structures with Shallow Foreshores: 2D Model Tests with Single and Double-Peaked Wave Energy Spectra; Delft Hydraulics/Waterbouwkundig Laboratorium: Delft, The Netherlands, 1999.

5. Altomare, C.; Suzuki, T.; Chen, X.; Verwaest, T.; Kortenhaus, A. Wave overtopping of sea dikes with very shallow foreshores. Coast. Eng. 2016, 116, 236-257. [CrossRef]

6. Van Gent, M.R.A. Wave run-up on dikes with shallow foreshores. ASCE J. Waterw. Port. Coast. Ocean. Eng. 2001, 127, 254-262. [CrossRef] 
7. Van Gent, M.R.A. Numerical model simulations of wave propagations and wave run-up on dikes with shallow foreshores. In Proceedings of the Fourth Conference on Coastal Dynamics, Lund, Sweden, 11-15 June 2001.

8. Munk, W.H. Surf beat. Eos Trans AGU 1949, 30, 349-854.

9. Tucker, M.J. Surf beats: Sea waves of 1 to 5 min. period. Proc. R. Soc. A 1950, 202, 565-573.

10. EurOtop. European Overtopping EurOtop Manual for the Assessment of Wave Overtopping; 2007; Available online: http://www.overtopping-manual.com/eurotop/downloads/ (accessed on 11 May 2020).

11. Hofland, B.; Chen, X.; Altomare, C.; Oosterlo, P. Prediction formula for the spectral wave period $\mathrm{T}_{\mathrm{m}-1,0}$ on mildly sloping shallow foreshores. Coast. Eng. 2017, 123, 21-28. [CrossRef]

12. TAW. Technical Report on Wave Run-Up and Wave Overtopping at Dikes; Technical Advisory Committee on Flood Defence: Delft, The Netherlands, 2002.

13. Hoan, L.X.; Hanson, H.; Larson, M.; Donnelly, C.; Nam, P.T. Modeling shoreline evolution at Hai Hau beach, Vietnam. J. Coast. Res. 2010, 26, 31-43. [CrossRef]

14. Phan Khanh, L. Wave Attenuation in Coastal Mangroves: Mangrove Squeeze in the Mekong Delta. Ph.D. Thesis, Delft University of Technology, Delft, The Netherlands, 2019.

15. Tas, S. Coastal Protection in the Mekong Delta: Wave Load and Overtopping of Sea Dikes as Function of Their Location in the Cross-Section, for Different Foreshore Geometries. Master's Thesis, Delft University of Technology, Delft, The Netherlands, 2016; pp. 17-18.

16. US Army Corps of Engineers. Shore Protection Manual; US Army Corps of Engineers: Washington, DC, USA, 1984; Volume 1.

17. Metocean Criteria for the Thaibinh Development Blocks 102 \& 106, Offshore Vietnam; Petronas Carigali Vietnam Limited: Ho Chi Minh City, Vietnam, 2011.

18. Stelling, G.; Zijlema, M. An accurate and efficient finite-difference algorithm for non-hydrostatic free-surface flow with application to wave propagation. Int. J. Numer. Methods Fluids 2003, 43, 1-23. [CrossRef]

19. SWASH User Manual: SWASH Version 3.14A; The SWASH Team: Delft, The Netherlands, 2016.

20. Suzuki, T.; Altomare, C.; Veale, W.; Verwaest, T.; Trouw, K.; Troch, P.; Zijlema, M. Efficient and robust wave overtopping estimation for impermeable coastal structures in shallow foreshores using SWASH. Coast. Eng. 2017, 122, 108-123. [CrossRef]

21. Chen, X.; Hofland, B.; Altomare, C.; Suzuki, T.; Uijttewaal, W. Forces on a vertical wall on a dike crest due to overtopping flow. Coast. Eng. 2015, 95, 94-104. [CrossRef]

22. Chen, X. Impacts of Overtopping Waves on Buildings on Coastal Dikes. Ph.D. Thesis, Delft University of Technology, Delft, The Netherlands, 2016.

23. Hofland, B.; Diamantidou, E.; van Steeg, P.; Meys, P. Runup and overtopping measurements with a laser scanner. Coast. Eng. 2015, 106, 20-29. [CrossRef]

24. TCVN 9901:2014 Hydraulic Structures-Requirements for Seadike Design, Vietnamese Version, 2014. TCVN 9901:2014 Công trình thủy lợi-Yêu cầu thiết kế đê biển, Hà Nội 2014; Thuyloi University: Hanoi, Vietnam, 2014.

(C) 2020 by the authors. Licensee MDPI, Basel, Switzerland. This article is an open access article distributed under the terms and conditions of the Creative Commons Attribution (CC BY) license (http://creativecommons.org/licenses/by/4.0/). 